\title{
方向交代性上向性頭位眼振症例の検討
}

\author{
長沼 英明 - 徳増 厚二・藤野 明人・吉尾知 \\ 新田健太郎・野口 浩男 ·星野功
}

\section{Positional Nystagmus of Direction Changing Type, Toward the Upper Ear Side}

\author{
Hideaki Naganuma, Koji Tokumasu, Akito Fujino, Satoshi Yoshio, \\ Kentaro Nitta, Hiroo Noguchi and Isao Hoshino \\ (Kitasato University School of Medicine)
}

Nystagmus towards the upper ear side in both lateral head positions is usually asociated with disturbance in the central nervous system, especially with the lesion in the brain stem or cerebellar posterior vermis.

Fifty patients in whom such positional nystagmus was detected in the ENG test during the last 8 years were investigated. In only 6 cases among them was such positional nystagmus observed under Frenzel spectacles. In these patients, the continual term of the nystagmus and association with positional vertigo were surveyed retrospectively. There were 16 cases of central disturbance, 32 cases of peripheral vestibular disturbance, and 2 cases of congenital idiopathic nystagmus. The central disturbances included vertebrobasilar insufficiency in 6, acoustic tumor in 2, cerebellar tumor in 2, multiple sclerosis in 2. The peripheral vestibular disturbance cases included 11 of recurrent vertiginous attacks, 5 of provocations-vertigo, 5 of labyrinthitis induced middle ear inflammation, and 4 of sudden deafness.

Positional nystagmus towards the upper ear side is consisted to be on important sign of the central disturbance but it may occur in the peripheral vestibular lesion. In the latter case, the positional nystagmus is associated with positional vertigo and disappears for a short time without neurological findings except positional nystagmus.

Key words: positional nystagmus of direction changing type, peripheral vestibular disturbance, central nervous disturbance, Electronystagmography

はじめに

方向交代性上向性頭位眼振は中枢神経系障害, 特に脳幹及び小脳虫部の障害によって認められ ることは従来よりよく知られている1) 6). しか し一方では末梢前庭障害によっても同眼振は生
じ得るといら報告7) 11) も散見され，その責任 病巣が中枢神経系だけではないとも考学られて いる.

我々は ENG 記録で同眼振が認められた症例 についてその原因疾患, 運動視標追跡検査, 視 
運動性眼振検査について検討した。さらにその 中でフレンツェル眼鏡下で同眼振が認められた 症例飞おいてはその持続期間, 頭位性めまいの 有無, 眼振の回旋成分の有無について検討した.

\section{対象・研究方法}

北里大学病院に拈いて，1981年 1 月上り 1988 年12月までの 8 年間に平衡機能検查を施行し， 方向交代性上向性頭位眼振が ENG 記録上検出 できためまい.平衡障害症例のうち，良性発作

\section{表 1 年秢分布}

$\begin{array}{lr}10 \text { 歳代 } & 1 \\ 20 " & 7 \\ 30 " & 8 \\ 40 " & 14 \\ 50 " & 10 \\ 60 " & 6 \\ 70 " & 4 \\ 80 " & 0\end{array}$

\section{合 計}

50 症例

40歳代をピークに10〜70歳代にわたっ てほぼ正規分布をなしていた。

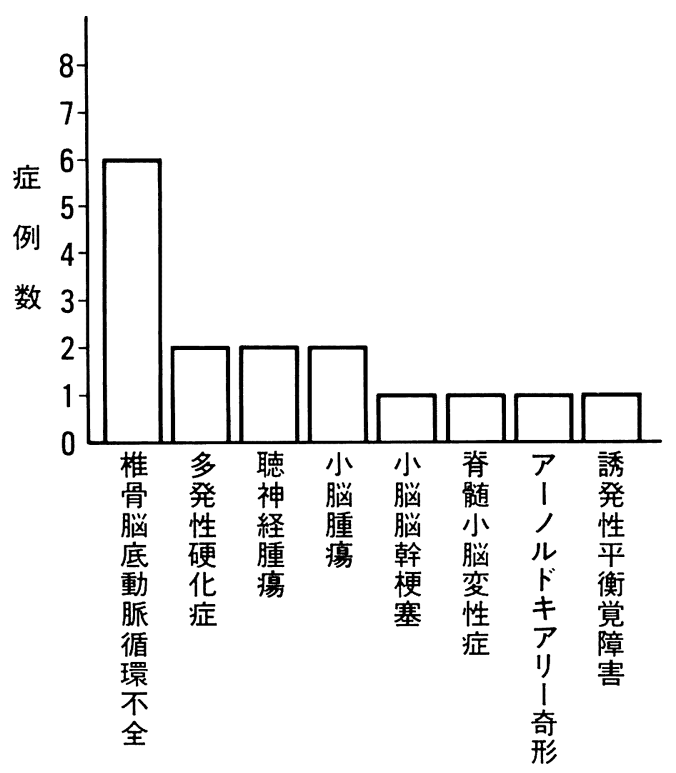

図１原因疾患（中枢性）
性頭位眩暈症と診断された 8 症例と眼振が純回 旋性であった症例を除外した50症例を対象とし た.

\section{結果}

$1 ）$ 性比・年齢分布

性比は, 男性21症例, 女性29症例であった。 年齢分布は40歳代の 14 症例をピークに 10 歳代〜 70 歳代にわたって注涪正規分布をなしていた (表 1 ).

\section{2 ）原因疾患}

同眼振を示した症例の責任病巣を示す，中枢 性に原因が求められる症例は16症例，末梢性に 原因が求められる症例は32症例であった。 その 他 2 例は先天性眼振症例であった。

中枢性に原因が求められる症例の原因疾患は 椎骨脳底動脈循環障害が 6 症例で最も多く, 次 いで聴神経腫瘍, 多発性硬化症, 小脳腫瘍が各 々 2 症例であった（図 1 ）。末梢性に原因が求 められる症例の原因疾患は反復性平衡覚障害が

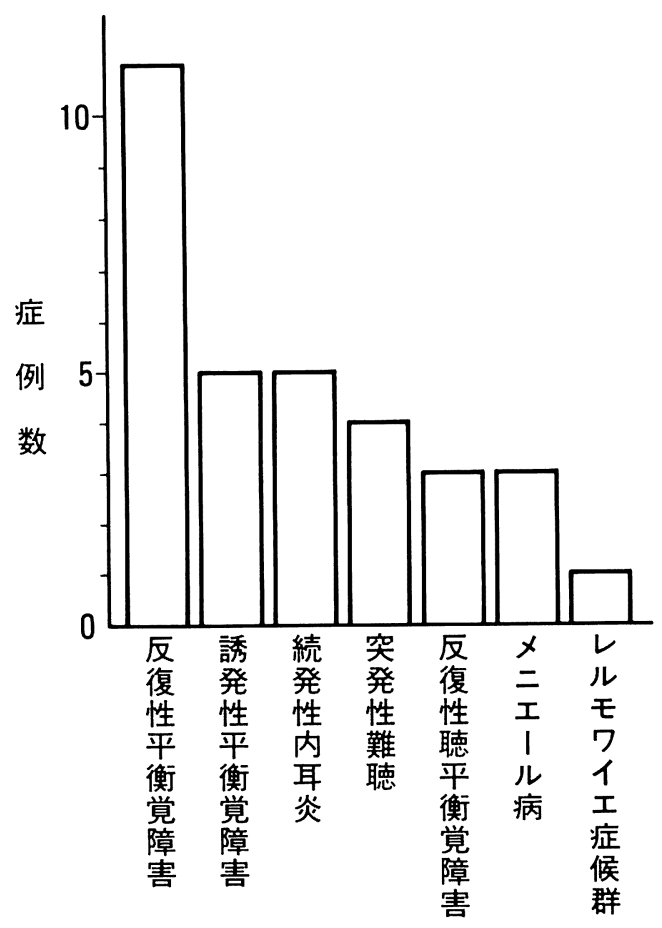

図 2 原因疾患（末梢性） 
11症例で最も多く, 続発性内耳炎, 誘発性平衡 覚障害が各々 5 症例, 突発性難聴が 4 症例であ った（図 2 ).

3 ）運動視標追跡検査 (ETT)

同眼振を示した症例を中枢，末梢両群に分け 検討した.

検査を施行し得た症例について両群を比較し てみると， saccadic パターンを示した症例は中 枢群では 15 症例中 6 症例 $(40 \%)$ ，末梢群では 32 例中 1 症例 $(3 \%)$ であり, 中枢群に saccadic パターンを示す症例が多かった（表 2).

4 ) 視運動性眼振 $(\mathrm{OKP})$ 検査

OKP 方式の検査を施行し得た症例について 同様に両群に分けて検討した，反応低下を示し た症例は中枢群では14症例中 8 症例 $(57 \%)$ ， 末梢群では 30 症例中 1 症例（3\%）であり，中 枢群で反応低下を示す症例が多かった（表 3 ).

表 2 ETTを施行し得た症例

saccadic を示した症例

中枢群：6 症例/15症例 (40\%)

末梢群：1 症例/32症例 (3\%)

saccadic パターンを示した症例は, 中枢

群で多く末梢群では 1 例.
このように ETT, OKP 検査での両群の比較 で，中枢群にそれぞれ saccadic パターン，反 応低下を示す症例が多かった。しかしこの結果 は同眼振を示さない中枢神経障害でも同様であ り，同眼振を示す症例に特徵的とは言えない。

同眼振が経過中に認められた末梢前庭障害症 例を示す。

〈症例〉

66歳, 女性

現病歴：昭和50年に時計回りの回転性めまい が出現し, 同時に両側耳鳴, 左難聴を自覚した. その後 $2 \sim 3$ 回の同様のめまい発作を繰り返し ていた。昭和58年10月22日朝，回転性めまい, 両側耳鳴（特に左耳鳴強い）を認め昭和58年10 月29日に初診となる。

初診時所見：左感音難聴を認めたが（図 3 ）, 注視・自発・頭位眼振はなく，その他神経学的

表 3 OKP を検査を施行した症例

反応低下を示した症例

中枢群：8症例/14症例 (57\%)

末梢群： 1 症例 / 30 症例 (3\%)

反応低下を示した症例は, 中枢群で多く 末梢群では 1 例.

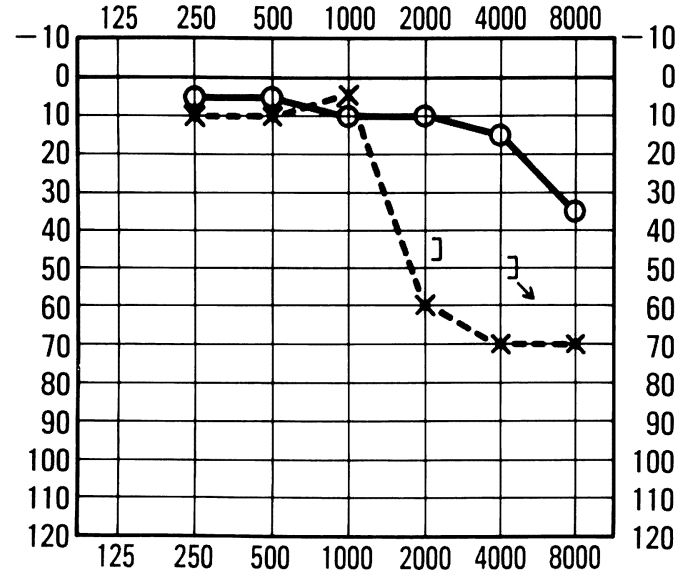

10月29日

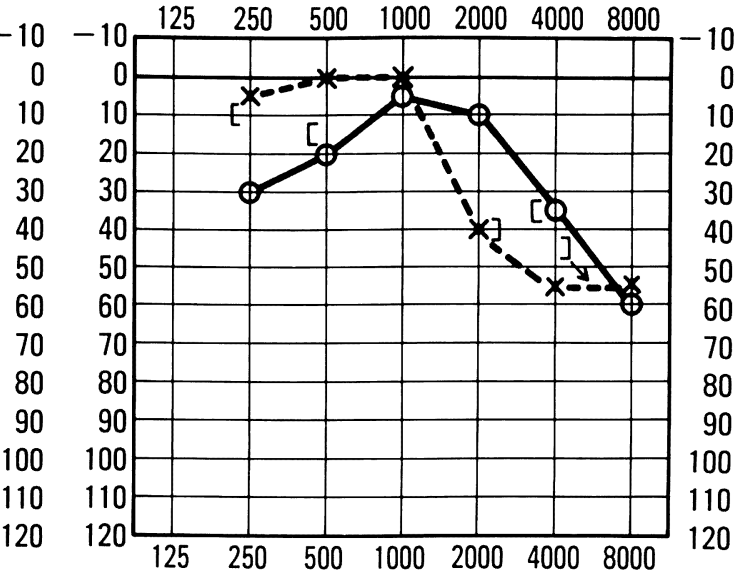

11月 1 日

図 3 症例の聴力検查所見 
異常所見も認められなかった.

経過・検査：11月 1 日に再診. めまい感は持 続して，フレンツェル眼鏡下，頭位眼振，頭位 変換眼振検查にて方向交代性上向性頭位眼振が 認められた（図 4)。また純音聴力検査で両側 感音難聴と, 右聴力の変動が認められた(図 3 ). 更に域値上聴力検査では, 語音最高明瞭度は右 耳 $60 \mathrm{~dB}$ で $88.1 \%$, 左耳 $90 \mathrm{~dB}$ で $86.6 \%$, SISI は $4 \mathrm{KHz}$ 右耳 $60 \mathrm{~dB}$ で $100 \%$, 左耳 $80 \mathrm{~dB}$ で $100 \%$ で両側リクルートメント陽性, 両側内耳 性難聴と判定された。平衡機能検査では ENG にて方向交代性上向性頭位眼振が認められ（図 5 ), ETT 正常, OKP は右正常, 左軽度反応 低下であった，その後もめまい症状が続くため

\section{注視眼振検査}

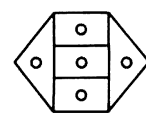

坐位頭位眼振検査

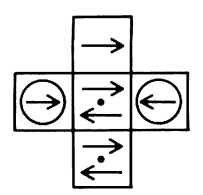

\section{頭位変換眼振検査}

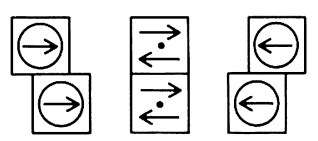

図4 症例の眼振所見（昭和58年11月 1 日） 頭位性めまいを随伴する方向交代性上向性頭位眼 振を認める.

図中○はめまい随伴

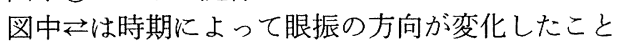
を示す。

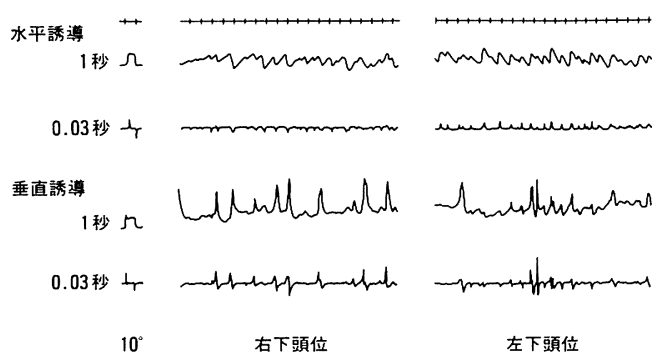

図 5 症例の ENG 検查所見（昭和58年11月 1 日） 方向交代性上向性頭位眼振が認められる。較正は $10^{\circ}$, 時標は 1 秒, 表中数字は時定数.
11月 8 日に精査治療目的にて入院となった。入 院時フレンツェル眼鏡下頭位眼振, 頭位変換眼 振検査にて右向き水平性眼振を認め，11月11日 の温度検査では両側 CP であった。 入院中もそ の他の神経学的異常は認められず, 頭部 CT 所 見にも著変がないことから両側メニエール病と 診断された，その後左耳鳴は続いたが，徐々に めまい症状が落ち着き，11月24日に退院した。

本症例は眼振以外に神経学的異常所見が認め られず，方向交代性上向性頭位眼振は頭位性め まいを随伴し，短期間で消失したことから責任 病巣は末梢前庭性と診断された。

\section{考按}

同眼振の成因について諸々の報告がある. 重 野ら ${ }^{8)}$ は比重の異なる薬剤を一側の中耳腔に注 入することによって，比重の違いに応じた方向 交代性（上向性, 下向性）頭位眼振モデルを作 製し，同眼振の責任病巣を内耳に求得るとし ている。また池田ら ${ }^{9)}$ は，方向交代性上向性頭 位眼振は一側前庭障害例に拄いて，主として中 枢神経系によると思われる代償過程で生じた可 能性があり, その発生機序には末梢前庭, 中枢 両者が関与していると報告している. 竹森ら は, 同眼振は内耳障害に括いても見られるとし， 内耳病変が刺激状態から機能低下状態に移行す る過程, 又, 機能低下状態から徐々に回復して いく過程で同眼振は生じ得ると報告している. 又 Nylén ${ }^{12)}$ は, 急性中耳炎が内耳炎に進展した とさに見られる眼振所見の変化を 5 期に分け, その第 3 期における両側前庭の相互作用が再障 害される時に方向交代性頭位眼振が生じ得ると 述べている．このように末梢前庭障害でも同眼 振が出現するといわれているが，それでは中枢 性障害で認められる同眼振とどのように区別す ればよいのだろらか。

今回 $\mathrm{ENG}$ 検査上, 同眼振を示した症例につ いて，フレンッェル眼鏡検査でも同眼振を検出 できた 5 症例を検討した（表 4 ）。吉本 ${ }^{13)}$ は， 中枢性の方向交代性眼振は上向性の頻度が下向 性より高く, 回旋成分がなく, 頭位性めまいが 
少なく, 持続が長い傾向にあると述べている(表 5 ). 検討 5 症例では，回旋成分が，中枢性で 存在する症例や，末梢性で存在しない症例があ った．頭位性めまいは聴神経腫瘍で存在せず, 末梢性症例では全例に見られた。持続期間につ いては，末梢性症例では同眼振は全例 1 両日で 消失したのに対して，中枢性症例では各々13日， 41日と比較的長期であった。

以上の結果から，頭位性めまいの有無，持続 期間は，同眼振が末梢性障害によるものか中枢 性障害によるものかの鑑別点として有用である と考学られた。
つまり，一般に同眼振はテント下障害で出現 するとされているが，眼振以外の神経学的異常 所見が認められず，頭位性めまいを伴い，眼振 が短期間で消失する例には末梢前庭性障害例が 含まれていると考えられた。

\section{結語}

1. 1981年 1 月から1988年12月までの 8 年間 に精密平衡機能検查を施行し，方向交代性上向 性頭位眼振が ENG 上検出できた症例の内，良 性発作性頭位眩量症と診断された 8 症例と純回 旋性眼振症例 1 例を除外した50症例について検 討した。

表 4 フレンツェル眼鏡でも同眼振が認められた症例

\begin{tabular}{|c|c|c|c|c|c|}
\hline & \multicolumn{3}{|c|}{ 末 梢 性 } & \multicolumn{2}{|c|}{ 中 枢 性 } \\
\hline 例 & 1 & 2 & 3 & 4 & 5 \\
\hline 祄 断 & $\begin{array}{l}\text { 誘 発 性 } \\
\text { 平衡障富 }\end{array}$ & 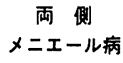 & $\begin{array}{c}\text { 反径性 } \\
\text { 衈平街莧障害 }\end{array}$ & $\begin{array}{c}\text { 椎骨稱底動眽 } \\
\text { 睬環席害 }\end{array}$ & 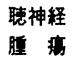 \\
\hline 回旋成分 & $\Theta$ & $\Theta$ & $\oplus$ & $\Theta$ & $\oplus$ \\
\hline 頭位性めまい & $\oplus$ & $\oplus$ & $\oplus$ & $\Theta$ & $\Theta$ \\
\hline 持統期間 & 2 日 & 1 日 & 1 日 & 41日 & 13日 \\
\hline
\end{tabular}

末梢性は頭位性めまいを随伴し，持続期間が比較的短期で あり，中枢性は頭位性めまいを随伴せず，持続期間は比較 的長期である.

表 5 方向交代性頭位眼振の鑑別 一各障害部位別にみた出現例に拈ける所見の特徵一

(吉本 裕 : $1985^{13)}$ より改変)

\begin{tabular}{|c|c|c|}
\hline & 中 枢 & 梢 \\
\hline 方 向 & 上向性が多い & $\begin{array}{l}\text { 下向性が多い } \\
\text { ※上向性のこと有 } \\
\text { 経過中に方向変化有 } \\
\text { (定方向性↔方向交代性, 上向性↔下向性) }\end{array}$ \\
\hline 性 状 & 純水平性多い & 水平回旋混合性多い \\
\hline 頭位性めまい & 少ない & 有 \\
\hline 再現性 & 有 & $\begin{array}{l}\text { 少ない } \\
\text { (fatiguability } \oplus)\end{array}$ \\
\hline $\begin{array}{l}\text { 経 過 } \\
\text { 艺の他 }\end{array}$ & $\begin{array}{l}\text { 持続性 } \\
\text { rebound positional nyst }(+) の こ と \text { 有 }\end{array}$ & $\begin{array}{l}\text { 一過性 } \\
\text { 潜伏時間 }(+)\end{array}$ \\
\hline 責任部位 & $\begin{array}{l}\text { 後頭盍窝障害 } \\
\text { (小脳>脳幹) }\end{array}$ & 内 耳 \\
\hline
\end{tabular}


2. 同眼振は一般には中枢性と考光られてい るが，特に眼振以外に神経学的異常所見がなく， 頭位性めまいを随伴し，眼振の経過が短い症例 の中に末梢性が含をれていると考えた.

3. 同眼振が認められた末梢性前庭障害（両 側メニエール病）症例を示した。

稿を終えるに臨み御指導, 御校閱いただきました, 北里大學耳鼻咽喉科学教室設楽哲也教授に深謝いた します。

尚, 本論文の一部は第48回日本平衡神経学会総会 （平成元年11月23日，奈良）において口頭発演した。

\section{参考文献}

1）坂田英治：裸眼ないしは Leuchtbrilleを用いた 検査がめまい.平衡障害の診断に，どこまで助 けとなりらるか.耳鼻臨床 $63:$ 431〜463, 1970.

2）志賀 敦, 清藤武三, 川野六郎, 他 : 頭位眼振 および頭位変換眼振に関する臨床的考察. 耳鼻 $15: 50 \sim 59,1969$.

3) 町井浩一：頭位眼振関する臨床的観察. 主と して中枢性, 未梢性眼振の比較. 新潟医学会誌 $69: 1111 \sim 1120,1955$.

4) Grant G, Aschan G and Ekvall L : Nystagmus produced by localized cerebellar lesions. Acta otolaryngol Suppl $192: 78 \sim 84,1964$.

5) Cohen B and Highstein SM : Cerebellar control of the vestibular pathways to oculomotor neurous Progress in Brain Research (ed by Brodal A and Pompeino O). Basic aspect of central vestibular mechanismsVol 37. pp 411
425, Elsevier, Amsterdam, 1972.

6) Uemura $T$ and Cohen $B$ : Vestibulocular reflexes; effect of vestibular nuclear lesions. Progress in Brain Research Vol 37 (ed by A Brodal and O Pompeino). pp $515 \sim 528$, Elsevier, Amsterdam, 1972.

7）竹森節子, 関要次郎, 相羽 正：頭位性めまい 症例について（良性発作性頭位胘量症を除く）. 耳喉 $58: 561 \sim 567,1986$.

8）重野浩一郎, 中島成人, 江上徹, 他: 実験的 万向交代性上向性頭位眼振モデルの作製. 耳鼻 臨床 $75: 2484 \sim 2490,1982$.

9）池田元久, 武藤二郎, 山積博彦, 他 : 方向交代 性上向性頭位眼振 3 症例の経過観察. 耳鼻 34 : 465 471, 1988.

10）野村公寿，川西由美子，内藤 明：ENG 飞拉 ける方向交代性上向性頭位眼振の検討. 耳喉 52 : 935 941, 1980.

11）長沼英明, 徳増厚二, 藤野明人, 他 : 方向交代 性上向性頭位眼振の成因の検討一頭部外傷症例 を中心に一. 耳鼻臨床 $83: 869 \sim 874,1990$.

12) Nylén $\mathrm{CO}:$ Positional nystagmus. - A review and future prospects. J Laryngol Otol $65: 295$ $\sim 318,1950$.

13）吉本 裕 : 方向交代性頭位眼振の診断的意義を めぐって. Equilibrium Res $44:$ 26〜28, 1985.

$$
\left(\begin{array}{l}
\text { 別刷請求先 : 長沼英明 } \\
\text { 个228 相模原市北里 } 1-15-1 \\
\text { 北里大学医学部耳鼻咽喉科学教室 }
\end{array}\right)
$$

